$34: 1064$

<原 著 $>$

肝硬変の肝血行動態の研究一thioacetamide による

ラット肝硬変モデルを用いた検討

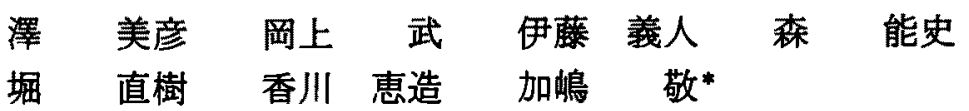

要 旨：thioacetamide(TAA)腹腔内投与により作成したラット肝硬変モデルの肝および全身 血行動態を radioactive microsphere methodを用いて検討した. 肝硬変群ではヒト乙型肝硬変 に相当する肝組織像で, 対照群に比へ有意な門脈圧六進と門脈大循瓄シャントの形成を認めた。 肝硬変群では, 全身および腹部内淢臓器の hyperdynamic circulationの結果生じ門脈流入血 流量の增加と門脈血管抵抗上界を認め, それらが門脈王六進の成因と考えられた。シャント血 流を除いた有奻肝血派量の検討では，肝硬变群は対照群に比べて低下傾向を示した。

TAAによる肝硬变モデルはヒト肝硬变とほば同様の機序による hepatic portal hypertension を持ち, 今後の肝硬変における門脈圧六進症を対象とした研究に有用な実験モデルと考文 た.

索引用語：肝硬変 門脈王穴進症 thioacetamide 肝血行動態

目的

肝硬変ではこの門脈王六進をはじめとして肝血行動 態に種々の变動が生(゙ーー3), それらは肝硬変の病態に大 きな影響を与えている゙．肝硬変に和ける門脈殴元進 は門脈血管抵抗の上昇がその成因とされてきた $か^{(5,6)}$ ，近年，門脈血流量の増加も成因の一つと考之ら れるようになっだ,8. また，肝硬変では肝のみならず 全身血行動態にす変化が出現することが報告されてい

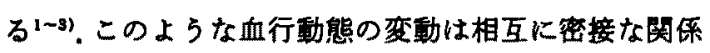
を持ち，全体像を把暒するには種々の湘定が必要とな る. 一般的に肝血行動態の検討には観血的検查を必要 とし，ヒトを対象とする場合には検查に際しての侵蛼 などが問題となり，詳細な検討が困難となる。従って， 血行動態の測定が比敖的容易な動物モデルを用いた榆 討が必要となる。

著者らは thioacetoamide(TAA) 投与により作成し たラット肝硬変モデルを対象に, radioactive microsphere method (MS 法) 用いて，肝および全身血行動 態の検討を行い, 同モデルが門脈王六進, 門脈一大循 謤シャントを有し，肝硬変の血行動態の俟討にふさわ しいモデルであることを明らかにすることとした。

- 京都府立医科大学第 3 内科

〈受付日1990年 3月 9 日 $>$
万 法

a）実験モデル 肝硬変群 (LC 群) は, 5 週龄の Wistar 系婎性ラ, トに tioacetoamide 12 週間投与 $(200 \mathrm{mg} / \mathrm{kg} \mathrm{bw}, 2 /$ 週，i.p.) し作成し， 2 週間の休菜後に実験に供した。 対照群(C 群)には同様に生食水を投与した。両群とも 16時間の絶食後に hemodynamic studyを行った.

b) Hemodynamic study

覚醒時ラットの心拍出量, 跟器血流量（胃, 膰を含 む小渴，大腸，脾、肝，堅，心，肺）をMS 法を用い

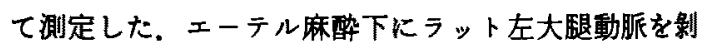
離し、ボリエチレンカテーテル (INTRAMEDIC PE50, Becton Dicknson \& CO., U.S.A.) を㨉入した, 次に右顓動脈を䟝離し，同部よりポリエチレンカテー テルを挿入し，血圧モ二ター下に先端を左心室内に進 め, 留瞋した。 2 本のカテーテルの遠位側はラットの 皮下を通して背部より出し，血流湘定時までへバリン ブロックを行った．カテーテル㨉入に必要な操作は皮 间の切開以外鈍的に行い，出血量を最少限とした。

2 時間以上の覚醒時間後, 左心室カテーテルより ${ }^{85} \mathrm{Sr}$ でラベルされた直径 $15 \mu \mathrm{m} の$ microshere (NEN. TRAC MICROSPHERS, DUPONT, U.S.A.) を15秒 間で注入した. microspere 注入の15秒前より，吸引ボ ンプを用いて $1.06 \mathrm{~m} l / \mathrm{min}$ の一定速度で左大䭆動脈カ 
テーテルからサンプル血を75秒間採血した，注入した microspere の数は30,000より60,000個で，生理食塩水 $0.2 \mathrm{ml}$ 照濁液として用いた. $1 \mathrm{cc}$ 注射器に吸引した microshere 生理食塩水懸濁液は注入直前に放射線活 性 (cpm) を $\boldsymbol{\gamma}$-シンチレーションカウンターを用いて 測定した. microspere 注入終了直後より30秒間で, 左 心室カテーテルを生理食塩水 $0.5 \mathrm{~m} l$ でフラシュした。

採血終了後，左大腿動脈カテーテルより $0.6 \mathrm{ml}$ の生 食水に溶解した pentobarbital $(25 \mathrm{mg} / \mathrm{kg})$ をゆっくり 注入し、ラットを麻醉した。

左季助下皮何に小切開を加之，笳肉，腹膜を鈍的に

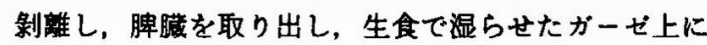

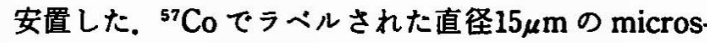
phere を脾実質内に注入し, Chjkier らツの方法を用い て門脈大循環シャント (portol systemic shunting: PSS）を測定した，脾を腹腔内に戻し，繾合した。

次に，約 $2 \mathrm{~cm}$ の腹部正中切開を加之門脈，下大静脈 にカテーテルを挿入，閉腹後，王トランスデュサーを 用いて門脈压 (portal pressure: PP), 中心静脈圧 （central vein pressure : CVP）を測定しポリクララフ に記録した。 また，すへての実検操作中，末梢血王 (mean arterial pressure : MAP), 心拍数 (heart rate : HR）をモニターリンクし，記録を残した。

pentobarbital 麻醉下の実験中, 直腸温が37.5土 0.5 Cを保つようヒーターを用いてラットを加温した。 pentobarbital を追加し、ラットを屠殺後，䁍器を摘 出し, 各贜器およびサンブル血の ${ }^{55} \mathrm{Sr},{ }^{57} \mathrm{Co}$ 放射線活性 を, エネルギー範囲の別に $\gamma_{\text {-シンチレーションカウン }}$ ターを用いて測定した。

$$
\begin{aligned}
& \text { 心拍出量 (cardiac output) = } \\
& \frac{\text { 注入 MS の } \mathrm{cmp}\left({ }^{85} \mathrm{Sr}\right)}{\text { サンブル血の } \mathrm{cpm}\left({ }^{85} \mathrm{Sr}\right)} \\
& \text { メサンブル血吸引速度 } \\
& \text { 缄器血流量 }(\mathrm{OBF})= \\
& \frac{\text { 組織の } \mathrm{cpm}\left({ }^{85} \mathrm{Sr}\right)}{\text { サンプル }} \\
& \text { メサンブル血吸引速度 } \\
& \mathrm{PSS}(\%)=\frac{\text { 肺の } \mathrm{cpm}\left({ }^{57} \mathrm{Co}\right)}{\text { 秆と肺の } \mathrm{cpm}\left({ }^{57} \mathrm{Co}\right) \text { の合計 }} \times 100 \\
& \text { 門脈流入血流量(portal venous inflow)= } \\
& \text { 胃十小腸十大腸十脾踫の OBF } \\
& \text { 実効門脈血流量(portal blood flow) }= \\
& \text { 門脈流入血流量 } \times 100-\text { PSS } 100 \\
& \text { 肝動脈血流是 (hepatic arterial blood flow)= }
\end{aligned}
$$

\section{肝の OBF}

肝血流量 (hepatic blood flow) $=$

門脈血流量十肝動脈血流量

得られた血流量はすべてラット体重 $1 \mathrm{~kg}$ 当たりに換 算 $(\mathrm{m} l / \mathrm{min} / \mathrm{kg} \mathrm{bw})$ して検討した。注入 MS の cpm は, 注入前に測定した cpmより注入後の注射器および 左心室カテの cpm を引いた値とした。

以上より得られた結果から, 次の値を算出した。

全末梢血管抵抗(total peripheral resistance) $=$

$$
\frac{\mathrm{MAP}-\mathrm{CVP}}{\mathrm{CO}}
$$

門脈側副路血管抵抗(portocollateral resis-

$$
\text { tance })=\frac{P P-C V P}{\text { portal venous inflow }}
$$

腹部内臓動脈血管抵抗(splanchnic arteriolar

$$
\text { resistance })=\frac{\text { MAP }- \text { CVP }}{\text { portal venous inflow }}
$$

門脈血管抵抗(portal venous resistance) $=$

$$
\frac{\text { PP-CVP }}{\text { portal blood flow }}
$$

単位はすべて $\mathrm{mmHg} / \mathrm{m} l \cdot \mathrm{min} \cdot \mathrm{kg}$ bw

$$
\text { 成繶 }
$$

TAA 投与した LC 群のラット肝表面は小結節状 で，組織像ではヒト乙型肝硬变類似の所見であった。 LC 群の一部の肝組織像はヒト甲型肝硬変類似の像を 呈した (Fig. 1).

LC 群では肝脾腫と血清トランスフミラーゼの有意 な上昇を認めた（Table 1).

全身血行動態の検討では，末梢平均血圧，中心静脈

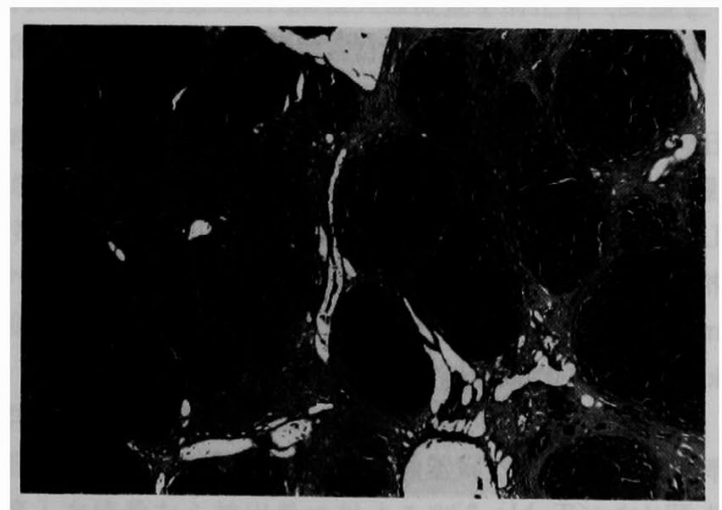

Fig. 1 Histologic finding of the liver in the thioacetamide treated rat. Marked regenerative nodules and fibrosis are seen. Azan-Mallory stein. $\times 70$ 
Table 1 Background

\begin{tabular}{l|c|c|l}
\hline & $\begin{array}{c}\text { Control } \\
(\mathrm{n}=15)\end{array}$ & $\begin{array}{c}\text { Cirrhosis } \\
(\mathrm{n}=24)\end{array}$ & $\mathrm{p}<$ \\
\hline body weight $(\mathrm{g})$ & $453 \pm 12$ & $421 \pm 42$ & 0.01 \\
liver weight/kg bw (g) & $27.06 \pm 0.56$ & $35.21 \pm 3.55$ & 0.001 \\
spleen weight/kg bw (g) & $2.56 \pm 0.34$ & $4.13 \pm 0.72$ & 0.001 \\
ALT (IU/l) & $24.00 \pm 7.27$ & $67.33 \pm 19.21$ & 0.001 \\
AST (IU/l) & $226.80 \pm 55.75$ & $428.89 \pm 117.40$ & 0.001 \\
T-Bil (mg/d $l)$ & $0.37 \pm 0.07$ & $0.34 \pm 0.13$ & NS \\
\hline
\end{tabular}

Velues are mean \pm SD. NS, not statistically significant

Table 2 Systemic Hemodynamics

\begin{tabular}{|c|c|c|c|}
\hline & $\begin{array}{l}\text { Control } \\
(\mathrm{n}=15)\end{array}$ & $\underset{(n=24)}{\text { Cirrhosis }}$ & $p<$ \\
\hline$\underset{(\mathrm{mmHg})}{\operatorname{mean} \text { arterial pressure }}$ & $97.6 \pm 5.3$ & $95.4 \pm 7.7$ & NS \\
\hline$\underset{\left(\mathrm{mmH}_{\mathrm{g}}\right)}{\text { central vein pressure }}$ & $2.3 \pm 0.9$ & $2.4 \pm 1.0$ & NS \\
\hline heart rate & $357.7 \pm 42.1$ & $346.3 \pm 39.8$ & NS \\
\hline cardiac output $(\mathrm{ml} / \mathrm{min} / \mathrm{kg} \mathrm{bw})$ & $260.2 \pm 37.5$ & $305.2 \pm 87.9$ & 0.05 \\
\hline $\begin{array}{l}\text { total peripheral resistance } \\
\left(\mathrm{mmHg} / \mathrm{ml} \cdot \mathrm{min}^{*} \mathrm{~kg} \mathrm{bw}\right)\end{array}$ & $0.344 \pm 0.047$ & $0.315 \pm 0.063$ & 0.05 \\
\hline
\end{tabular}

Values are mean $\pm S D$. NS, not statistically significant ;

Table 3 Organ Blood Flow

\begin{tabular}{l|c|c|c}
\hline \multicolumn{1}{c|}{$\begin{array}{c}\text { Blood Flow } \\
(\mathrm{m} l / \mathrm{min} / \mathrm{kg} \mathrm{bw})\end{array}$} & $\begin{array}{c}\text { Control } \\
(\mathrm{n}=15)\end{array}$ & $\begin{array}{c}\text { Cirrhosis } \\
(\mathrm{n}=24)\end{array}$ & $\mathrm{p}<$ \\
\hline liver & $6.10 \pm 2.3$ & $5.90 \pm 5.11$ & NS \\
portal venous tributary & & & \\
$\quad$ stomach & $6.47 \pm 1.84$ & $10.22 \pm 3.76$ & 0.001 \\
small intestine & $32.51 \pm 9.35$ & $50.18 \pm 9.36$ & 0.001 \\
large intestine & $9.71 \pm 2.13$ & $10.71 \pm 2.59$ & NS \\
spleen & $5.33 \pm 1.24$ & $8.24 \pm 2.81$ & 0.001 \\
kidny & $50.30 \pm 7.15$ & $53.81 \pm 10.03$ & NS \\
heart & $16.58 \pm 6.45$ & $18.41 \pm 9.97$ & NS \\
lung & $8.13 \pm 5.30$ & $48.90 \pm 74.03$ & 0.01 \\
\hline
\end{tabular}

Values are mean \pm SD. NS, not statistically significant ;

圧，心拍数は両群間に差はなかったが，LC群で心拍出 量は有意に增加 $(\mathrm{C}: 260.2 \pm 37.5 \mathrm{~m} l / \mathrm{min} / \mathrm{kg} \mathrm{bw，}$ LC : $305.2 \pm 87.9 \mathrm{ml} / \mathrm{min} / \mathrm{kg} \mathrm{bw} ; \mathrm{p}<0.05) \mathrm{L}$, 全末 梢血管抵抗は有意に低下 (C：0.344 $\pm 0.047 \mathrm{mmHg} /$ $\mathrm{m} l \cdot \mathrm{min} \cdot \mathrm{kg}$ bw, LC $: 0.315 \pm 0.063 \mathrm{mmHg} / \mathrm{m} l \cdot \mathrm{min} \cdot$ kg bw ; p<0.05) していた (Table 2).

各臟器レベルでの検討を行うと，LC群で胃，小腸， 脾䁍の門脈上流の䑏器お゙よび肺の OBF の有意な増加 を認めた（Table 3)。

両群の各臟器血流量, 門脈血流量を心拍出量に占め る割合で比較检討すると，LC群では門脈血流分画が 有意に増加( $\mathrm{C}: 20.7 \pm 4.5 \%$, LC : $26.0 \pm 5.0 \% ； \mathrm{p}<$

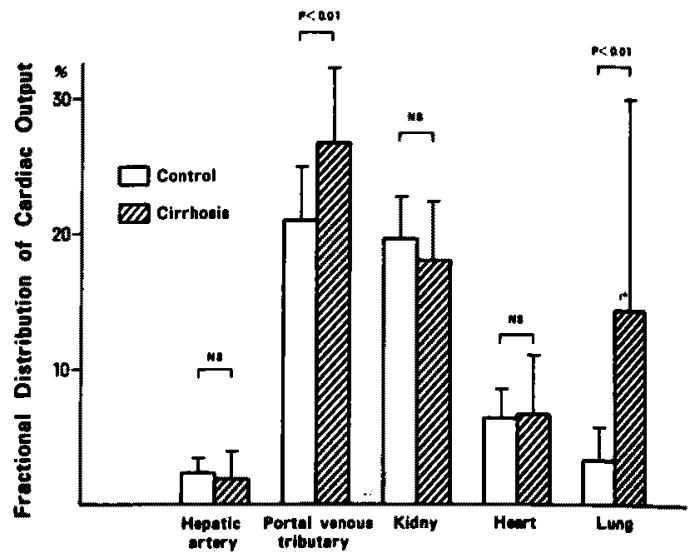

Fig. 2 Fractional distribution of cardiac out put to liver and other organs.

0.01)していた (Fig. 2).

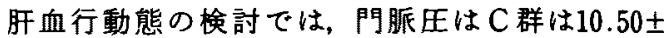

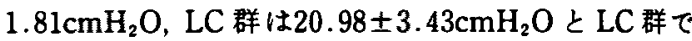

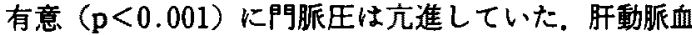
流量は両群間に有意差はなく，門脈流入血流量(portal

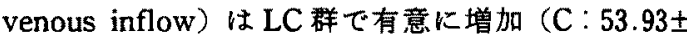
$11.63 \mathrm{ml} / \mathrm{min} / \mathrm{kg}$ bw, LC: $79.39 \pm 15.00 \mathrm{ml} / \mathrm{min} / \mathrm{kg}$ bw：p<0.001）していた。門脈一大循環シャント (portal systemic shunting) はC 群では認めなかった が，LC 群で有意に形成されていたＣ：0.32士0.46\%， LC : $38.15 \pm 33.13 \% ； \mathrm{p}<0.001)$ ．シャント血流を除 外した実効門脈血流量（portal blood flow）はC 群で $53.76 \pm 11.51 \mathrm{~m} l / \mathrm{min} / \mathrm{kg}$ bw，LC 群で $48.47 \pm 25.79$ $\mathrm{m} l / \mathrm{min} \mathrm{kg}$ bw と LC 群で有意差はなかったがやや娍 少傾向にあった，肝動脈血流量之実効門脈血流量の合 計である肝血流量 (hepatic blood flow) む LC 群で有 意差はなかったが減少傾向にあった（C：60.05士 $11.38 \mathrm{ml} / \mathrm{min} \mathrm{kg} \mathrm{bw,} \mathrm{LC} \mathrm{:} 53.74 \pm 26.62 \mathrm{ml} / \mathrm{min} / \mathrm{kg}$ bw：NS)。門脈側副路血管抵抗 (portcollateral resis-

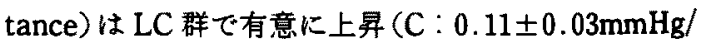
$\mathrm{m} l \cdot \mathrm{min} \cdot \mathrm{kg}$ bw, LC : $0.17 \pm 0.03 \mathrm{mmHg} / \mathrm{m} l \cdot \min \cdot \mathrm{kg}$ bw：p<0.001）していた。門眽血管抵抗（portal venous resistance) す同様に LC 群で有意な上昇 (C： $0.11 \pm 0.03 \mathrm{mmHg} / \mathrm{ml} \cdot \mathrm{min} \cdot \mathrm{kg}$ bw, LC : $0.56 \pm 0.77$ $\mathrm{mmHg} / \mathrm{ml} \cdot \mathrm{min} \cdot \mathrm{kg}$ bw $; \mathrm{p}<0.01)$ を示した（Table 4).

\section{考察}

近年、旰疾患における肝血行動態の異常が病態や病 因に密接に関係するものとして注目されている10,11! 
Table 4 Splanchnic Hemodynamics

\begin{tabular}{|c|c|c|c|}
\hline & $\begin{array}{l}\text { Control } \\
(n=15)\end{array}$ & $\begin{array}{l}\text { Cirrhosis } \\
(n=24)\end{array}$ & $\mathbf{p}<$ \\
\hline portal pressure $\left(\mathrm{cmH}_{2} \mathrm{O}\right)$ & $10.50 \pm 1.81$ & $20.98 \pm 3.43$ & 0.001 \\
\hline $\begin{array}{l}\text { hepatic artery blood flow } \\
(\mathrm{ml} / \mathrm{min} / \mathrm{kg} \mathrm{bw})\end{array}$ & $6.10 \pm 2.31$ & $5.90 \pm 5.11$ & NS \\
\hline $\begin{array}{l}\text { portal venous inflow } \\
(\mathrm{ml} / \mathrm{min} / \mathrm{kg} \text { bw) }\end{array}$ & $53.93 \pm 11.63$ & $79.39 \pm 15.00$ & 0.001 \\
\hline $\begin{array}{l}\text { portal blood flow } \\
(\mathrm{ml} / \mathrm{min} / \mathrm{kg} \text { bw })\end{array}$ & $53.76 \pm 11.51$ & $48.47 \pm 25.79$ & NS \\
\hline $\begin{array}{l}\text { hepatic blood flow } \\
(\mathrm{m} l / \mathrm{min} / \mathrm{kg} \text { bw })\end{array}$ & $60.05 \pm 11.38$ & $53.74 \pm 26.62$ & NS \\
\hline $\begin{array}{l}\text { splanchnic arteriolar } \\
\text { resistance } \\
(\mathrm{mmHg} / \mathrm{m} / \cdot \mathrm{min} \cdot \mathrm{kg} \text { bw) }\end{array}$ & $1.65 \pm 0.27$ & $1.07 \pm 0.27$ & 0.001 \\
\hline $\begin{array}{l}\text { portocollateral resistance } \\
(\mathrm{mmHg} / \mathrm{m} l \cdot \mathrm{min} \cdot \mathrm{kg} \text { bw })\end{array}$ & $0.11 \pm 0.03$ & $0.17 \pm 0.03$ & 0.001 \\
\hline $\begin{array}{l}\text { portal venous resistance } \\
(\mathrm{mmHg} / \mathrm{ml} \cdot \mathrm{min} \cdot \mathrm{kg} \mathrm{bw})\end{array}$ & $0.11 \pm 0.03$ & $0.56 \pm 0.77$ & 0.01 \\
\hline $\begin{array}{l}\text { portal systemic shunting } \\
(\%)\end{array}$ & $0.32 \pm 0.46$ & $38.15 \pm 33.13$ & 0.001 \\
\hline
\end{tabular}

Values are mean \pm SD. NS, not statistically significant ;

肝硬変の重篤な合併症である食道静脈瘤破裂は門脈 元進により生じることや，訮性媨症が門脈大循環シャ ントと密接な関係を持つことより，肝血行動態につい て多くの検討がなされてきだーい.肝硬变における門脈 王穴進症は線維化や偽小葉形成に起因する肝内の門脈 系の血管抵抗上昇によるものとされてきたが5,6)，近 年, 腹部消化器曂器の hyperdynamic circulution の結 果生じる門脈流入血流量の增加すその成因の一つと考 えられている7,8,12)。それに加えて, 肝硬变では門脈大循 環シャントが形成され, 肝血行動態の変動はより一層 複雑となる．また，肝硬变では腹部や肝の血行動態の みならす心拍出量の増加や末梢血管抵抗の减少とい。 た全身血行動態の変動が生じることも報告されてい $ろ^{1-33}$. 肝硬変では上記のような広範な血行動態の変動 が出現し，相互に複雥に関与するため，その全体像を 把握するには複数の測定での詳細な検討が必要とな る.

肝硬変の血行動態の検討はこれまでヒトを対象にし たすのが多かったが1-4)，検査の侵望などの点から，多 種の全身血行動態や肝血行動態の検討を同時に行った あのは少ない，近年，各種動物実験モデルを用いた㭘 討が增加しているが6ー8,12,13)，肝血行動態を検討するた めの肝硬変モデルとしては，ヒト肝硬変で臨床上問題 となる門脈圧え進と門脈大循環シャントを有すること が必頁である.ラットを用いた肝硬变モデルとして四 塩化炭素䀒障害が使用される事が多いが14)，このモデ ルでは肝の線維化や偽小葉形成は軽度で，かつ血行動
態の検討においても前記の条件が十分満たされていな い名. また，四塩化炭素肝硬变ては肝細胞の ballooning が門脈血管抵抗增加に大きな役割を持ち6)，これらの 点むとトで主としてみられるゥイルス起因の肝硬変と は異なる機序と考えられる. Groszmann らて 9,15)は ラット門脈本幹結愁による門脈王六進症モデルを作成 し血行動態を険討している，同モデルは門脈圧六進， 高度の門脈大循環シャント, hyperdynamic circulationが存在することから門脈殴六進症モデルとして 適当なるのと考えられる。しかし，同モデルは prehepatic portal hypertension であり, 肝内に病变は無く， hepatic portal hypertension であるヒト肝硬変の肝血 行動態の検討に代わるすのとは言い難い．

今回の検討に用いた TAAによる肝硬変モデルは， 欧米で使用されることは多いが16,17，本邦での報告は 少ない，本剂の投与により，RNAの代謝阻害や mitochondria 細胞膜が直接障害され肝硬変が生じると されているが16)，偽小葉形成や線維隔壁などの肝組織 所見る四塩化炭素モデルに比べよりヒト肝硬変に近い 像である ${ }^{77}$. 血行動態の検討では，対照群に比べ約 2 倍 に達する門脈圧六進と門脈大循環シャントの形成を認 めた，すなわち，ヒト肝硬変と同様の hepatic portal hypertensionがしたものと考えられる.かつ,このモ デルは週 2 回の腹腔内投与で俆硬变を容易に作成可能 であり，所硬変時の血行動態検討に有用なモデルであ る.

今回の血行動態の検討に用いた MS 法は小動物の 血流測定に適した方法で，心拍出量と複数の㼨器血流 量を同時に測定し得る ${ }^{18)}$. 肝血流量を門脈，肝動脈の 別々に測定可能で，門脈流入血流量を消化管（脺菜も 含む）と脾缄の血流量の合計より求める。門脈血流は 上流の消化器や脾䑏への血流により規定されることを 考虑すると，肝血行動態の変動を検討するには有用で ある.また， portal systemic shunting を併せて測定 することよりり，閒脈流入血流量とンャント血流を除 外した実奻門脈血流量を愉討することが可能で，肝硬 変モデルの肝血流の検討に適している.

今回の検討では, 肝硬変群は門脈流入血流量は対照 群に比し有意に增加し，その增加は主に胃，小腸の上 部消化管の血流量の増加より生じていた。 また，門脈 流入血流量を心拍出量に対する割合として検討して も, 肝硬変群ではコントロール群に比べて有意に増加 していた，すなわち，䀒硬変では心拍出量の血流分配 に変化が生し，門脈流入血流量が增加したと考えられ 
る.このよらな splanchnic hyperdynamic circulation は腹部内臓贜器の血管拡張により生じたと考えられる か，本検討でも腹部内葴動脈血管抵抗は肝硬変群で有 意に減少していた，血管の拡張により，粘膜下 での動脈一静脈短絡が出現した可能性も考えられ ろ ${ }^{19)}$ 。このよらな血管㹡張の機序は未だ明らかにされ ていないが，肝硬变で增加を示す各種血管拉張物質の 関与が考えられている20).

門脈血管抵抗とシャント血管も含めた門脈側副路血 管抵抗は肝硬变群では有意に増加していた，TAAに よる肝硬変モデルでは門脈血管系の血管抵抗增加と腹 部臓器の hyperdynamic circulationにより門脈王六 進が生じたと考えられる。

肝硬変群では門脈流入血流が增加しても, 門脈大循 環シャントが生しており実效門脈血流量は対象群に比 べ低下傾向にある。旰動脈血流量は両群間に有意差は なく，肝動脈と有効門脈血流量の和を肝血流量（hepatic blood flow)として恰討すると，肝硬変群では减 少する傾向にあった.

全身血行動態の検討では，肝硬変群で心拍出量の増 加と全身末梢血管抵抗の减少を認めた。にト訮硬变を 対象とした検討です同様の報告があり1-3\}，その原因は 䛻環血液量の増加中酸素消費量の増加 ${ }^{2} k$ 加之, 腹部 内臓藏器での hyperdynamic circulation と同様の機 序が推湘されているるる,13). その他の亚器血流量の検討で は，心蔵，腎臓の血流量は両群間に有意差はなかった が, 肝硬変群で肺の䠞器血流量の増加を認めた. 肝硬 变では末梢血管での動静脈シャントの開通が報告され ておりそのため肺での microsphere の集積が生した 可能性が考えられる.

\section{結 語}

1) thiocetamide 投与によるラット肝硬変モデルを 用い, 肝硬変時の肝および全身血行動㿟の恋動を検討 した。

2）肝硬变群では門脈正六進と門脈大㡒環シャント の形成が存在した。

3）肝硬变群では門脈血管抵抗の増加と腹部内葴お よび全身の hyperdynamic circulationを認めた。

4） thioacetamide 肝硬変モデルはヒト肝硬变と同 様の肝血行動態の変化を示し, 血行動態検討モデルと して有用であった。

\section{文献}

1) Kowalsi HJ, Abeljmann WH: The cadiac output at rest in Laennec's cirrhosis. J Clin
Invest $32: 1025-1033,1953$

2) Heinemann HO : Respiration and circulation in patients with portal cirrhosis of thee liver. Circulation 22 : 154-159, 1960

3) Murray JF, Dawson AM, Sherlock S: Circulatory change in chronic liver disease. Am J Med $24: 358-367,1958$

4) Boyer TD: Portal hypertension and its complications. In : Hepatology, edited by Zakim D and Boyer TD. WB Saunders, Philadelphia, 1982, p464-499

5) Popper H, Hutterer F: Hepatic fibrogenesis and disturbance of hepatic circuration. Ann NY Acad Sci $170: 88-99,1970$

6) Sibayama $Y$, Nakata $\mathrm{K}$ : Localization of increased hepatic vascular resistance in liver cirrhosis. Hepatology 5 : 643-648, 1985

7) Vorobioff J, Bredfeldt JE, Groszmann RJ: Hyperdynamic circulation in portalhypertensive rat model : a primary factor for maintenance of chronic portal hypertension. Am J Physiol 244 : G52-57, 1983

8) Vorobioff J, Bredfeldt JE, Groszmann RJ: Increased blood flow through the portal system in cirrhotic rats. Gastroenterology 87: 1120 $-1126,1984$

9) Chojkier N, Groszmann RJ : Measurement of portal-systemic shunting in the rat by using $\gamma$-labeled microspheres. Am J Phisiol 240 : G371 $-357,1981$

10) Sawa $Y$, Okanoue $T$, Kanaoka $H$, et al: Pathogenesiss of portal hypertension in alcoholic liver disease. In : Biomedical and Social Aspect of Alcohol and alcoholism, edited by Kuriyama K, Takada A, Ishi H, Exerpta Medica, Amsterdam, New York, Oxford, 1988, p409-412

11）㳏美彦, 岡上 武, 金岡彦治, 他：急性フルュー ル投与時の肝血行哣態の検討一radioactive microsphere method を用いた模討. 肝漍 印刷中

12) Lebrec $D$ and Blanchet $L$ : Effect of two models of portal hypertension on splanchnic organ blood flow. Clin Sci 68: 23-28, 1985

13) Jeehey DJ, Betzelos $S$ and Daugird JT : Arteriovenous shunting in experimental liver cirrhosis in rats. J Clin Med 109: 687-691, 1987

14) Tamayo RP: Is cirrhosis of the liver experi. 
mentally produced by $\mathrm{CCl}_{4}$ an adequate model of human cirrhosis? Hepatology $3: 112-120$, 1983

15) Groszmann RJ, Vorobioff J, Riely E : Splanchnic hemodynamhcs in portal-hypertensive rats: measurement with $\boldsymbol{\gamma}$-labeled microspheres. Am J Pysiol 242: G156-160, 1982

16) Nuber R, Teutsch HF, Sasse D: Metabolic zonation in thioacetamide-induced liver cirrhosis. Histohemistry 69 : 277-288, 1980

17) Dashti H, Jeppson B, Hagerstrand I, et al: Thioacetamide-and carbon tetrachlorideinduced liver cirrhosis. Eur Surg Res 21 : 83-91,
1989

18) Isise S, Pegram BL, Yamamoto J, et al : Reference sample method: cardiac output and blood flow in conscious rats. Am J Phsiol 239 : H443-449, 1980

19）真辺忠雄、鉿木 敬, 本庄一夫：肝硬変時の胃潰灌 発生機序一胃血行動態よりの娭討. 日消誌 74 ： 40-51, 1977

20) Gerini N, Lee SS, Hadengue A, et al: Circulatory effect of somatostatin analogue in two conscious rat models of portal hypertension. Gastroenterology $94: 703-708,1988$

\title{
Systemic and hepatic hemodynamics in the experimental liver cirrhosis induced by thioacetamide administration
}

\author{
Yoshihiko SAwa, Takeshi OKanoue, Yoshito ITOH, Takashi MoRI, \\ Naoki HoRI, Keizo KagaWA and Kei KaSHIMA*
}

Systemic and hepatic hemodynamics in the experimental liver cirrhosis induced by thioacetamide treatment were evaluated using radioactive microsphere method. The histology of the rats was compatible with liver cirrhosis in human. In the cirrhotic rats, portal pressure and portal systemic shunting significantly increased compared with the controls. The increase of the portal venous inflow resulted from the systemic and splanchnic hyperdynamic circulation and the elevation of the portal venous resistance was observed in cirrhotic rats. These phenomena result in portal hypertension in the cirrhotic rats. Effective hepatic blood flow was decreased in the cirrhotic rats in spite of the increase of the portal venous inflow.

The thiocetamide induced cirrhotic rats showed a similar pathogenesis in the portal hypertension in the cirrhosis in human. Therefore, this model might be suitable for the study of the hemodynamics in the portal hypertension in cirrhosis.

* Third Department of Internal Medicine, Kyoto Prefectural University of Medicine (Kyoto) 